\title{
Understanding of Developing and Setting Tasks in Geography Lessons by German and Dutch Student Teachers
}

\author{
Uwe Krause $^{1, *}$, Alexandra Budke ${ }^{2}$ iD and Veit Maier ${ }^{2}$ (D) \\ 1 Department of Geography Education, Fontys University of Applied Sciences, \\ 5022 DM Tilburg, The Netherlands \\ 2 Institute of Geography Education, University of Cologne, 50923 Cologne, Germany; \\ alexandra.budke@uni-koeln.de (A.B.); veit.maier@uni-koeln.de (V.M.) \\ * Correspondence: u.krause@fontys.nl
}

Citation: Krause, U.; Budke, A.; Maier, V. Understanding of Developing and Setting Tasks in Geography Lessons by German and Dutch Student Teachers. Educ. Sci. 2021, 11, 63. https://doi.org/ 10.3390/educsci11020063

Academic Editor: James Albright Received: 18 January 2021

Accepted: 5 February 2021

Published: 8 February 2021

Publisher's Note: MDPI stays neutral with regard to jurisdictional claims in published maps and institutional affiliations.

Copyright: (c) 2021 by the authors. Licensee MDPI, Basel, Switzerland. This article is an open access article distributed under the terms and conditions of the Creative Commons Attribution (CC BY) license (https:// creativecommons.org/licenses/by/ $4.0 /)$.

\begin{abstract}
Setting tasks plays a key role in geography lessons, as they enable students to engage with the subject content, guide lessons towards predefined learning outcomes, and are therefore important for assessment. At the same time, the use of tasks is complex as numerous aspects regarding the content and the students have to be taken into account. Based on theoretical and empirical literature, we identify seven quality criteria for tasks in geography education: motivating and engaging students; addressing the heterogeneity of students; structuring learning processes; comprehensible formulation; considering individual and social learning processes; making meaningful use of materials; and fostering the development of subject specific competences. These criteria were applied in observation of lessons, which were given during an exchange between student geography teachers from a Dutch and German university. Overall, it was found that student teachers recognize the defined quality criteria, but half of them focus on only one or two aspects. The difficulties student teachers face in task setting during their traineeship can partly be explained by their phase of apprenticeship and the context. The developed observation form was considered to be valuable for preparation and observation of and reflection on tasks in geography lessons, and the exchange enabled student teachers to gain an insight into their own teaching practice.
\end{abstract}

Keywords: tasks; geography education; student teachers; observation; exchange; international comparison

\section{Introduction}

Research shows that the repertoire that geography teachers develop is partly dependent on the curriculum context the teacher is functioning in [1]. In order to get student teachers in an early stage of their career to reflect on their own teaching approach critically, comparative assessment in the form of an international exchange is deemed to be useful [2]. As setting questions and formulating tasks is a key skill for student teachers, and an important aspect of good teaching generally, we focus on these aspects here. Setting tasks is a vital part of geography lessons, as they encourage students to engage with the subject [3]. In the first part of the article, the international state of research concerning geography tasks is presented, followed by a set of key quality criteria for tasks derived from this research. Subsequently, the operationalisation of these criteria is presented in an observation form that can be used to observe the use of tasks in geography lessons. This form was applied in an international exchange seminar in which participants were asked about their understanding of tasks before and after an observation exercise. The foci of our research were students' ideas of quality criteria for geography tasks, difficulties experienced in task setting, and the impact of the observation form as well as the exchange. The results of this survey are presented and discussed. Finally, conclusions are drawn for the further development of the observation form and for its use in teacher training. 


\section{The Role of Tasks in Geography Lessons}

Tasks, which include questions, activities, or assignments, are a key tool for geography teachers as they enable students to engage with the subject. They can be used for summative and formative assessment, and promote the development of critical thinking, both subjectspecific and more broadly [3-7]. Recent research has shown that geography teachers in Germany and the Netherlands use tasks for more than 40 percent of lesson time in upper secondary education [1]. Approximately one third of these tasks were derived from the textbooks that the teachers use (ibid.).

First, we focus on various categorisations of tasks, subsequently concentrate on how tasks can foster higher order thinking, and finally present theoretical and empirical findings about tasks in geography lessons.

\subsection{Types of Tasks}

Based on Kleinknecht's [3] (p. 12) definition, we understand tasks as a request to students to engage with the content of a set subject. In this context, tasks are the link between the normative curriculum and the professional actions of teachers, with the goal of developing students' individual learning processes [8] (p. 1). As Matthes and Schütze [9] pointed out, a task always covers at least three aspects: a topic, a problem, and the execution of the task, in other words, solving the problem set in the task. Although there are various examples for the types of tasks that exist (ibid.), we identify three main types of categories. The first refers to the function of tasks in the lesson, e.g., learning processes, which include tasks for acquisition, application, or testing of knowledge [9,10]. The second category focuses on the acquisition of (subject) specific competences, such as map skills including map selection, map reading, and map production [11]. The third centralises on cognitive processes, as exemplified in Bloom's revised taxonomy [12], which in some cases is combined with the second category in order to create a subject specific taxonomy $[6,13,14]$. All categories of tasks define increasing levels of difficulty in terms of cognitive processes, which generally vary depending on the actions expected from the student, to what extend the student needs to apply existing knowledge, and the complexity of the resources/data that need to be manipulated [15] (pp. 43-44).

\subsection{Tasks for Lower and Higher Order Thinking}

A method by which distinction is often made between (geography) tasks is either lower and higher order thinking or lower, middle, and higher order thinking [16-19], which comes short of displaying meaningful variations in the lower category [20]. Depending on how the distinction is made [17], lower order thinking only includes tasks that aim to reproduce knowledge and rehearsed procedures. It can also include the application of thinking strategies belonging to the level of understanding outlined in Bloom's revised taxonomy [12], which consists of cognitive processes such as summarising, comparing, or recognising patterns. Higher order thinking is seen as desirable as it stimulates selfregulation of learning processes, leads to better learning results, and stimulates critical thinking and creative reflection. These tasks are therefore considered to be key for cognitive activation [21] (p. 402), and the development of powerful knowledge in geography lessons [22]. Powerful knowledge should be considered to be the most reliable form of knowledge about the natural and social worlds. It goes beyond personal experience, making it possible to think about alternatives for the future and providing a language for participation in societal debates [23]. As Béneker [24] identified, powerful knowledge should be viewed as the amalgam of five types of knowledge, of which all are important, but only when all of these types of knowledge are considered, do they have the potential to empower the learner. These five types of knowledge are (1) factual or concrete geographical knowledge, (2) conceptual and theoretical knowledge, (3) systematic knowledge as a result of the combination of the former two types of knowledge, (4) knowledge and language of societal debates referring to the ability to check information, solve problems, and underpin personal points of view through argumentation, and (5) knowledge of knowledge, 
which introduces students to the ways of knowledge production and discourses within the subject discipline. These five aspects are also, although in different ways, covered by the competence framework developed by the German Geographical Society [13]. On the way to the highest levels of higher order thinking (e.g., powerful knowledge), students increasingly engage with knowledge in its abstract and complex nature, which is called epistemic ascent [25]. Undertaking tasks is crucial for epistemic ascent in order to develop powerful knowledge.

\subsection{Tasks in (Geography) Lessons}

Generally, tasks are considered to be the most powerful tool for teachers in terms of guiding the teaching process and the students achieving the teaching objectives [26]. In order to close what Menck [27] calls the "didactical gap", the teacher has to have a clear idea about what the students know and do not know prior to undertaking the task. The teacher should also know what the students should learn through doing the task and the expected outcomes of the task. These outcomes are predominantly, but not solely, determined by curriculum documents, the intended curriculum [28]. However, tasks are also a very complex instrument as they involve the teacher having to make important decisions [29] in the form of selection, sequencing, pacing, and assessment. As Thijs and Van den Akker [30] identify, the teacher has to consider, within the 'curricular spider web', not only the content (what?) but also the relevance (why?), the students and grouping of students (with/by whom?), the way or strategy (how?), the resources (with what?), the place (where?), the lesson phase (when?), the amount of time (how long?), and the expected outcomes, which are all closely linked to teaching aims and formative or summative assessment, and finally their own role as a teacher. Furthermore, homework plays an important role as it is an integral part of the geography lesson [31] and, as a (geography) lesson rarely stands by itself, it has to be regarded as an element in a lesson series [32]. A crucial aspect of task setting is the debriefing [33], particularly if the task focuses on meta-strategies and the argumentation in students' answers. Numerous studies have proven the importance of self-regulation strategies in the acquisition of competencies [34] and argumentation in order to come to evidence-based evaluation or problem solving [35] so that higher order thinking, e.g., powerful knowledge, can be achieved.

\subsection{Empirical Findings about the Use of Tasks in Geography Lessons}

Recent empirical research in regard to tasks in geography education mainly concentrates on three aspects. Firstly, the research examines textbook tasks as part of the implemented curriculum concerning cognitive processes $[1,16,20,36,37]$ or specific aspects such as spatial thinking, spatial planning, or future orientation [6,38,39]. Findings show tasks in textbooks that focus on higher order thinking skills, more complex spatial thinking, and on future orientation and planning generally, are scarce in all examined curriculum contexts. Secondly, the use of tasks in geography lessons has been examined, and a focus on the cognitive processes the tasks foster [1,40], or on aspects related to tasks such as thinking skills, argumentation, or spatial planning has been identified [18,41,42]. These findings suggest that teachers rely on textbook tasks and use mainly lower order thinking tasks. However, there are differences between curriculum contexts. Furthermore, students show difficulty in applying more complex (geographical) skills, but interventions help both teachers and students, and improve results. Thirdly, research has focused on the influence of curriculum in terms of the type of tasks in geography textbooks and/or lessons [1,43], which show both an influence of the intended curriculum on the implemented curriculum, but also a gap between both.

\section{Quality Criteria for Tasks in Geography Lessons}

Based on theoretical literature and previously published empirical results, we have formulated the following quality criteria (see Figure 1) to be applied when setting tasks in geography lessons $[31,44,45]$. First, teachers should motivate and engage students 
in learning activities by creating a need to know. Second, tasks should consider the plurality of the students (age, cognitive skills, social background, learning styles), their prior and everyday geographical knowledge, and provide scaffolding, if necessary. Third, tasks should be structured in one of several ways, which consider the learning process (accumulating) and the lesson phase in relation to the curriculum aims. Learning results (output) should be secured in each lesson phase and during debriefing activities, metacognitive aspects should also be addressed. Fourth, tasks should be formulated precisely and visualised, so that students know what they are expected to do and in what time frame. The use of well-defined action verbs (such as summarise, compare, evaluate) can help them out. Fifth, tasks should encourage independent work by students and give them the possibility to come to their own conclusions, whilst also enabling cooperative learning that fulfils the criteria of successful collaboration. Sixth, tasks should provide multifaceted materials and address a broad scale of subject relevant skills. Finally, tasks should contribute to the development of subject-specific competences and foster higher order thinking. Here, classification frameworks proved to be helpful.

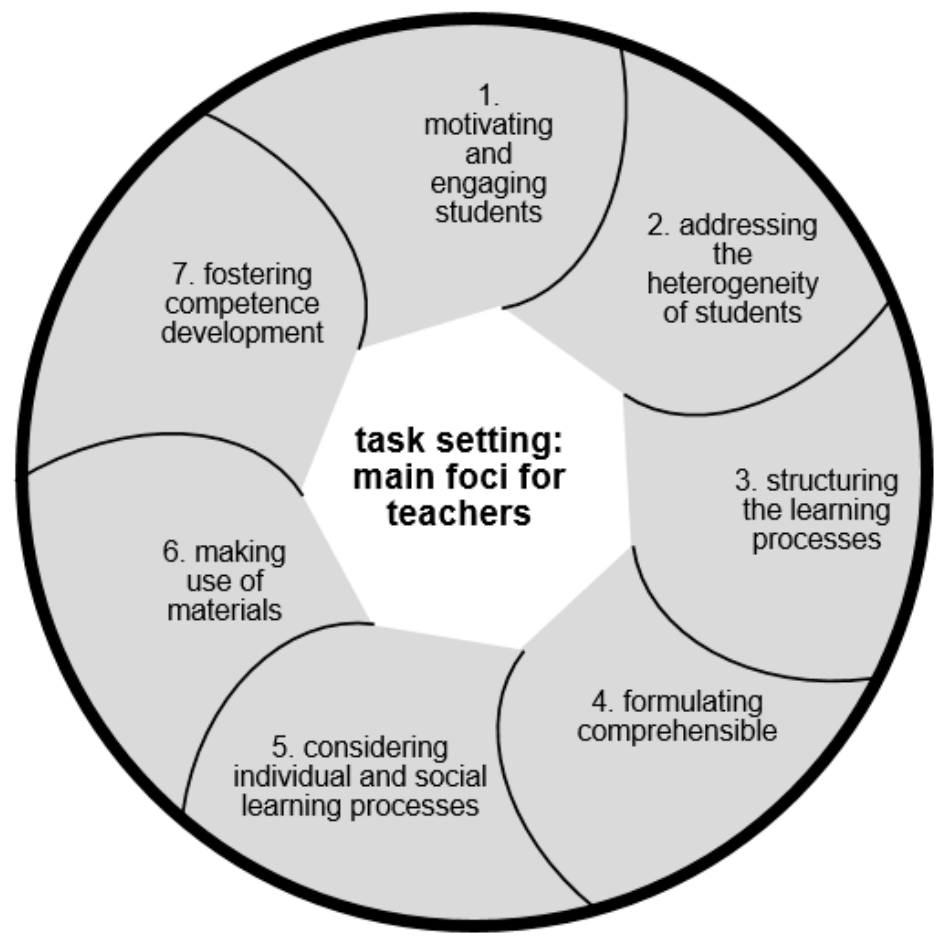

Figure 1. Quality criteria for developing and setting tasks and their use in geography lessons (authors' work).

\subsection{Quality Criteria for Tasks}

We agree with Diethelm et al. [46] that the teacher plays a vital, often underestimated, role in the process of didactical reconstruction that results in lesson planning. We understand task setting as part of the didactical structuring, which is strongly related to the lesson content and learners' perspectives. In order to make implicit decisions about the teacher in relation to task setting explicit [47], an observation form was developed based on the quality criteria for tasks in geography lessons, presented in the previous section (see Figure 1). In the following section, we outline how these criteria were derived from the available theoretical literature and how we applied them to the observation form (see Figure 2). The numbers and order in which we present the criteria does not indicate a hierarchical order. Although we initially present the quality criteria for tasks separately, in reality, the criteria influence each other. If, for example, the heterogeneity of the students is not taken into account, the increase in competence may also be negatively affected. 


\begin{tabular}{|c|c|}
\hline Observer: & \multirow{2}{*}{$\begin{array}{l}\text { School: } \\
\text { Number of students: }\end{array}$} \\
\hline Class: & \\
\hline \multicolumn{2}{|l|}{ Lesson topic: } \\
\hline Criteria & Task: \\
\hline \multicolumn{2}{|l|}{ Heterogeneity of students } \\
\hline Are there different/ differentiated tasks? & o Yes o No o I don't know \\
\hline Is there scaffolding (aid) in the task? & $\begin{array}{lll}\text { Visual o Yes } & \text { o No } \\
\text { Language o Yes } & \text { o No } \\
\end{array}$ \\
\hline Is there a reference to the scaffolding in the task? & o Yes o No \\
\hline \multicolumn{2}{|l|}{ Structuring Learning Processes } \\
\hline Is the task structured in steps? & o Yes \\
\hline Have interim results been secured? & o Yes \\
\hline Were the results debriefed and secured? & o Yes o No \\
\hline If yes, how? & $\begin{array}{l}\text { 1/2 / Group / Class } \\
\text { [ ] oral o Teacher o Students } \\
\text { [ ] written o Teacher o Students }\end{array}$ \\
\hline \multicolumn{2}{|l|}{ Comprehensibility } \\
\hline Have the tasks been clearly formulated? & o Yes \\
\hline In what way is the assignment set? & [] oral [] written \\
\hline Is a time frame given? & o Yes o No \\
\hline How long? & $\begin{array}{l}\text { Time: } \_ \text {m. o appropriate } \\
\text { o too long/short }\end{array}$ \\
\hline Is the task being explained in the classroom? & o Yes o No \\
\hline Are action verbs used (e.g. name, compare)? & o Yes \\
\hline \multicolumn{2}{|l|}{ If yes, which ones? } \\
\hline Do these action verbs make sense in relation to the lesson question? & o Yes \\
\hline \multicolumn{2}{|l|}{ Moderation of individual and social learning processes } \\
\hline Does the teacher support the students to solve the task? & o Yes \\
\hline If yes, does this support make sense here? & o Yes \\
\hline Is the grouping form given and is it meaningful to solve the task? & o Yes \\
\hline $\begin{array}{l}\text { Group work: is there mutual dependency of the group members (roles) to solve } \\
\text { the task? }\end{array}$ & o Yes \\
\hline \multicolumn{2}{|l|}{ Use of materials } \\
\hline Are there resources offered to solve the task? & o Yes \\
\hline Can the task be solved with the given resources? & o Yes \\
\hline $\begin{array}{l}\text { Does the task indicate with which material / how the students should come up } \\
\text { with an answer? }\end{array}$ & o Yes \\
\hline Development of competences & \\
\hline NL: In which category (taxonomy) can the task be classified? & $\begin{array}{l}\text { [] LOT [] UTS [] PHOT [] HOT } \\
\text { [] Reflection }\end{array}$ \\
\hline D: In which performance level can the task be classified? & $\begin{array}{l}\text { [ ] Perf. Level } 1 \text { [ ] Perf. Level } 2 \\
\text { [ ] Perf. Level } 3\end{array}$ \\
\hline Do the tasks promote cognitive activation? & o Yes o No \\
\hline Do the tasks gradually become more difficult? & o Yes \\
\hline Motivation and engagement of students & \\
\hline Were the tasks as a whole sufficient to finally answering the lesson question? & $\begin{array}{l}\text { o Yes o No } \\
\text { Remarks: }\end{array}$ \\
\hline Notes: & \\
\hline
\end{tabular}

Figure 2. Observation form (LOT = lower order thinking, UTS = use of thinking strategies, PHOT = parts of higher order thinking, HOT = higher order thinking, Perf. Level = performance level, “Anforderungsbereiche”') (Authors’ work). 


\subsubsection{Motivation and Engagement of Students}

An important aspect of tasks is that they motivate students by, what Roberts [45] calls, "creating a need to know". This is especially the case at the beginning of an enquiry sequence, where an overarching question derived from the key concepts of the subject should capture students' interest and imagination and guide their focus on one of geography's big ideas [48,49]. Furthermore, the enquiry question should stimulate students to engage with geographical data in order to be able to answer the question, and by doing so, promote development of skills and competences [50]. We acknowledge that motivation and engagement of students is key when setting tasks in geography lessons. However, whether students are motivated by a task is difficult to observe. In order to measure the affections of students, they would need to be interviewed or a more detailed observation would need to be undertaken in respect to this. Motivation is related to each of the quality criterion (see Figure 1), and as we specified earlier, there is a mutual influence between all aspects. However, learning goals can easily be forgotten [49,51] if the tasks offered are not appropriate in enabling students to answer the set question. We therefore added the question "Were the tasks, as a whole, sufficient to answer the lesson question?" to the observation sheet (see Figure 2).

\subsubsection{Heterogeneity of Students}

With the ratification of the UN Convention on the Rights of Persons with Disabilities, the member countries (including Germany and the Netherlands) have committed themselves in Article 24 to an "inclusive education system at all levels" [52]. However, inclusion should not only be understood as a measure for the integration of students with special educational needs, but as teaching that targets all students equally. Inclusion in a broad sense aims to do justice to the students' differences and heterogenic initial and environmental conditions in order to enable everyone to participate equally in educational and social processes, regardless of special educational needs [53] (p. 190). Students could be heterogeneous in respect to age, gender, talent, social, cultural or economic background, learning style, performance, etc. It is a huge task for student teachers to achieve this for all students.

The school system is organised vertically in Germany and the Netherlands $[54,55]$. Students are divided at the age of 10 or 12 based on their intellectual capacity using school marks. Other types of external differentiation include class level (within the school) or special educational orientations between types of schools (e.g., Dalton, Waldorf, Montessori education). Due to the importance of considering heterogeneity between students, internal differentiation (within the class) is gaining more importance. This means that the individual subjects or their subject education, in our case geography education, must develop suitable concepts for such application. As Goemans and Steegen [56] identified, differentiation in geography education can take place in respect to content [57], process [58,59], and output [60-62]. Tasks are key in the differentiation process, as requirements can be adapted to students' different abilities, interests, or prior knowledge. Consequently, we included the following question in the observation form: "Are there different/differentiated tasks for different students?"

Linked to the aspect of heterogeneity of students and the development of competences is the importance of a scaffolding. Scaffolding can be understood as a tiered, structural, and often metacognitive set of guidelines, which make it easier for students to process a task [56]. We therefore put the following questions in the observation form: "Is there scaffolding (aid)?" and "Is there a reference to the scaffolding in the task?"

\subsubsection{Structuring Learning Processes}

Tasks are important for each phase of a lesson. They should be linked to students' previous knowledge [63-66] because "things that do not connect to the cognitive structures are not perceived" [67] (p. 135). In addition, a link should be established with every day (geographical) knowledge [27,48,68-70], so that students can identify with the tasks [71]. 
All essential parts of the lesson content should be covered by tasks [72]. However, there is disagreement about the number of tasks that should be included in a lesson and their function. On one hand, too many tasks can interrupt the learning process of the students [72] (p. 166), particularly tasks that focus on rehearsing repeatedly have a negative influence $[71,73,74]$. On the other hand, as Helmke [70] and Tillmann [75] argue, without sufficient practice, a transfer of learnt knowledge is not possible. However, often these tasks are too difficult and hinder the access to the lesson content [72]. In such cases, the teacher assumes that the learner has already processed the material. Therefore, in a range of tasks, the first should focus on the acquisition of new content. Tasks, in which the learnt material is to be applied in a new context (transfer), should be able to be carried out correctly by 80 percent of the target group, and reproductive tasks by all learners. The sequence of tasks should therefore be systematic [65,72]: first reproductive questions, then questions with a focus on the application of knowledge, and finally higher order questions which, among other things, encourage the students to discuss and evaluate. Nevertheless, there is also disagreement with this kind of approach, as it would lead to a repetitive lesson scheme in which the student loses the overview of what should be learnt and why, and, as a result of this, becomes unmotivated [51]. The study suggests that the "whole task" should be given to the students first, and then various steps should follow. However, in both approaches, there is an acknowledgement that tasks can consist of consecutive steps, making it possible for students to solve more complex tasks, especially for those students with learning difficulties. Therefore, we added the question "Is the task structured in steps?" to the observation form. Furthermore, securing results in order to consolidate the learning outcomes is an important aspect when debriefing tasks [3,33]. This is valid for interim results, as well as debriefing at the end. This aspect was considered in the observation form by including the questions "Have the interim results been secured?" and "Were the results debriefed and secured? If yes, how?"

\subsubsection{Comprehensibility}

Models of communication explain the communication process between the sender and the receiver of a message. This communication process can be affected by obstacles [76]. In a school context, the teacher can be seen as the sender, the message is the task, and the receiver is the student. The obstacle can be difficulties in understanding due to unknown words, difficult sentence structure, or different expectations regarding the depth of a response etc. In class, it is important that teachers outline as precisely as possible what they expect of their students when they work on their tasks and ensure that the students understand the tasks before they start working on them, e.g., by encouraging oral questions and explanations. We aimed to include this aspect on the observation form through asking the following questions: "Has the task been clearly formulated?", "In what ways is the task set (oral or written)?", "Is a time frame given? How long?", and "Is the task being explained in the classroom?". The Educational Standards in Geography for the Intermediate School Certificate in Germany set requirements for the creation of tasks. These requirements include considering students' everyday life, problem orientation, cumulative construction of the tasks, variation in the types of task, use of action verbs (such as describe, compare, etc.) to ensure understanding and performance levels [12]. A list of action verbs has been included and linked to performance levels (ibid.). This is covered in the observation form by the following questions: "Are action verbs used (f. ex. name, compare)?", "If yes, which ones?" and "Do these action verbs make sense in relation to the lesson question?"

\subsubsection{Moderation of Individual and Social Learning Processes by the Teacher}

Tasks should, on the one hand, encourage students' self-regulation and make sure that students work independently $[64,70,77]$. However, the construction of the whole learning processes by textbook tasks is seen critically [78]. On the other hand, tasks should promote cooperative learning $[33,71,79,80]$, as not only is it considered to be a twenty-first century skill [45], but it also leads to better learning results [34]. Both ways of learning have to 
be supported by the teacher, and group work should follow clear rules, such as mutual dependency and clear roles for each group member [71,81]. These aspects have been considered in the observation sheet, by asking "Does the teacher support the students? If yes, does this support make sense here?", "Is the grouping form given and is it meaningful to solve the task?", and "Is there mutual dependency of the group members (roles) to solve the task?"

\subsubsection{Use of Materials}

Resources in geography education are the carrier of information and in this context the representation of real-world issues. Generally, a distinction is made between texts, graphs, tables, images (photos, drawings), schemes, and maps [72,77,82-86]. The retrieval of information from resources is an important part in PISA (Programme for International Student Assessment) tasks, especially when it comes to knowledge transfer [87] (p. 44) and is promoted by the German national standards [13] and by the Dutch curriculum [88]. However, there is criticism, particularly in the German context, that tasks often do not ask for more than the reproduction of information given [89], do not ask for more exhaustive analysis of the materials offered, and use data in elaborated argumentation structures, as required for higher order thinking $[35,90]$. When it comes to enquiries, in which students have to search for their own resources, processes such as identifying bias and judging the consistency of information are key $[12,45,48,66]$. The aspect of the use of materials is addressed in the observation form by the questions "Are there resources offered to solve the task?", "Can the task be solved with the resources?", and "Does the task show with which material/how the students should come up with an answer?"

\subsubsection{Development of Competences}

Geographical education is considered to be "vital to equip the next generation of people with the knowledge, skills, attitudes, and practices to value, care, and make reasoned decisions for the planet" [91] (p. 5). Next to the acquisition of knowledge and practical application, tasks should also activate cognitive processes of the students. According to Klieme [21], this becomes visible with an increasing complexity of tasks and demands for argumentation, which reflects the intensity of subject-specific learning. This increasing degree of difficulty should occur within a set of tasks during a lesson (series) as well as over time when working through the subject's curriculum and should lead to competence development. In the German case, competence areas have been outlined [13] as subject specific knowledge, spatial orientation, acquisition of knowledge/methodology, communication, evaluation, and action. For all six competence areas, three performance levels have been described, based on the uniform requirements for the high-stakes exam [92]: Performance level I is aimed at reproduction, Performance level II at reorganisation and transfer of knowledge, and Performance level III at evaluation and problem solving. As stated previously, action verbs (such as describe, compare, or discuss) have been officially defined and ascribed to these performance levels [93]. In the Netherlands, the curricula are defined for various levels of geographical skills and subject specific knowledge, which are specified by the Institute for Curriculum Development (SLO), and are applied to the high-stakes exams by the Board of Tests and Examinations (CvTE). Teacher training departments, textbook publishers, and schools work with various categorisations for tasks. Due to the gap being present between a feasible and reliable categorisation in order to identify cognitive processes tasks, the Geography Task Classification framework was developed. This is based on the sub-categories of Bloom's revised taxonomy [20]. This framework distinguishes between lower order thinking, use of thinking strategies, parts of higher order thinking, higher order thinking, and reflection and presentation. The Dutch participating students worked within this framework to address the development of competences. It is important that challenging tasks are also set in the classroom to enable students to deal with the subject matter in a creative way, although this is only partly the case in textbooks. Studies show that German and Dutch textbooks, for example, integrate very few argumentation 
tasks, challenging comparative tasks, and planning tasks [1,20,38,94,95]. The following questions are part of the observation form: "In which category (NL)/performance level (D) can the task be classified?", "Does the task promote cognitive activation?", and "Do the tasks gradually become more difficult?"

\subsection{Form for Observing the Use of Tasks in Geography Lessons}

In cooperation with German and Dutch students, a form was created based on the quality criteria for the tasks described above. This form enables the use of tasks in geography lessons to be observed and documented (Figure 2). The observations made in German and Dutch geography lessons, which were documented with the help of the form (Figure 2), were used for further reflection.

\section{Research Question}

As identified previously, the use of tasks is an important part of lesson planning, as well as in the teaching itself. However, the role of the teacher in this process of didactical reconstruction [46] is often underestimated, as are the difficulties teachers experience with regards to the putting theoretical knowledge into practice [96-98]. This is particularly true for student teachers, who have just begun to develop their subject didactical and pedagogical expertise $[99,100]$. However, we know that linking theory and practice in teacher education can foster meaningful learning and enhance deliberate practice [100-102], and that exchanges of student teachers from different contexts in terms of curriculum have a positive impact on student teachers' professional development [103].

Such an exchange, which focuses on subject-specific pedagogy, takes place on a yearly basis between geography student teachers of the University of Cologne (Germany) and Fontys University of Applied Sciences Tilburg (The Netherlands), and has done since 2016. The topic of the exchanges varies each year. In 2019/2020, the focus was on tasks and their use in geography lessons. As such, our research questions were:

Which aspects do geography student teachers indicate as quality criteria for tasks and task setting?

Which difficulties do geography student teachers experience during their traineeships in respect to task setting?

To what extent were the developed observation form (Figure 2) and the exchange helpful for the students with regards to task setting?

\section{Methodology}

\subsection{Course Themes}

In January 2020, we organised an exchange consisting of two groups of geography student teachers. The exchange is embedded in one university seminar in Cologne (Germany) and one seminar in Tilburg (Netherlands). Although seminars differed because of different priorities in teacher education, both had focus sessions on "Tasks in Geography Education". In addition to the aspects discussed in the theoretical section (Figure 1), the course in Cologne gave special attention to tasks focused on argumentation [104], problem based learning [105], comparing [42], and how to analyse tasks [106]. In the Dutch setting, emphasis was given to the function of tasks in relation to powerful geography teaching [48,107] and higher order thinking [20].

\subsection{Exchanges}

Both groups prepared geography lessons in small groups of 3-5 student teachers. The student teachers were asked to consider the theoretical aspects of their seminar in their lesson planning. The process of the exchange was identical in both countries. In a first meeting, the evening before the teaching took place, all lessons were briefly presented in English. Due to the different size of the groups, the German lessons were taught in three schools, and in the Netherlands in five schools, both in a lower secondary education setting (Figure 3). A group of Dutch student teachers visited a group of German student teachers 
and observed the lessons prepared for the German schools, using the observation form (compare Figure 2). All lessons were filmed. Following the class observation, the student teachers discussed the lessons in their groups. Both groups were asked to identify positive aspects and aspects to be improved regarding the tasks. The videos were used for this purpose. Afterwards, the Dutch and German student teachers discussed the use of tasks during the lessons and agreed on one positive teaching scene and a scene with potential for improvement in each school. The identified scenes and corresponding discussion were presented in front of all the student teachers.

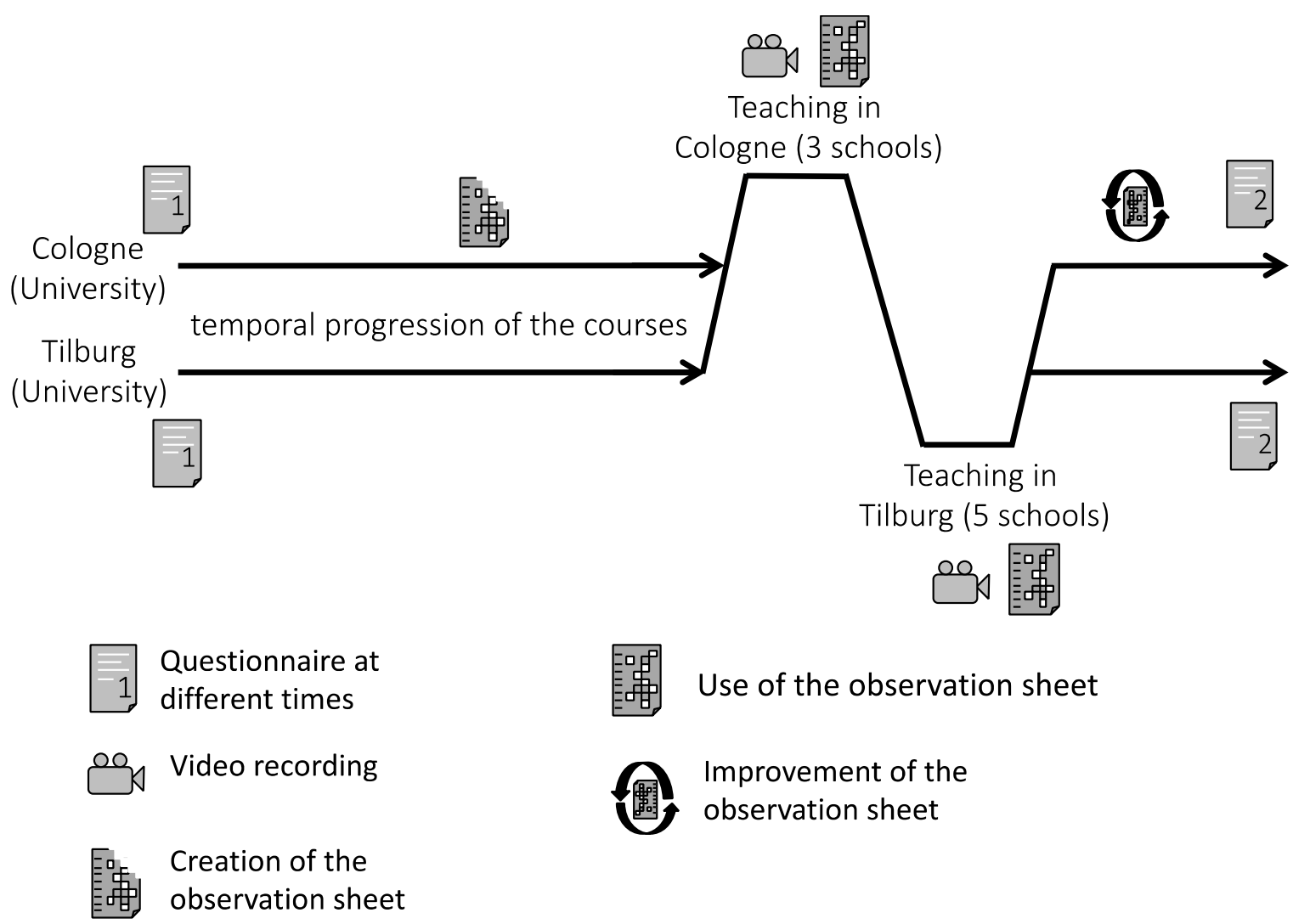

Figure 3. The process of the exchange seminar. Authors' design, based on Maier and Budke [2] (p. 47).

\subsection{Participants}

All participating students were studying geography teaching for lower secondary education, which is Haupt, Real, or Gesamtschule (class 5-10) in Germany and vmbo (class 7-10), havo, or vwo (class 7-9) in the Netherlands. The German student teachers were master students, the Dutch bachelor students. Nevertheless, the Dutch student teachers have a more practice-orientated education (spending half a year of each study year undertaking their traineeship in schools). The German student teachers have an internship lasting half a year during their master programme, but receive intensive practical training during a 1.5 year internship called Referendariat after finishing their studies. There is no equivalent of this in the Netherlands. Students do gain prior knowledge about tasks in general courses about subject didactics, but to which extent depends on the country and on the individual student. In both countries, training at schools can have an influence on knowledge and skills regarding quality criteria for task setting. Moreover, in Germany, student teachers study two subjects, which might also have an impact. The German group consisted of 12 student teachers aged between 22 and 45 years ( 3 male and 9 female), the Dutch group of 21 student teachers aged between 19 and 25 years (of which 4 female and 
17 male). However, only 19 of the Dutch and 11 of the German student teachers filled in the first questionnaire.

\subsection{Data Collection and Data Analysis}

We used pre-questionnaires to identify the previous knowledge and understanding that the student teachers had in respect to task setting, and we used post-questionnaires to ascertain the impact of the seminars, the exchange and the relevance of the observation sheet. The questionnaires were written in German and Dutch so that the student teachers were able to answer in their native tongue. All questions were open-ended.

The findings in this article are based on the following questions: What do you think are good tasks in geography lessons and why? Give two examples. As a teacher, what do you (still) find difficult when using tasks in geography lessons? These questions have been asked in the pre- as well as the post-questionnaire. In order to evaluate the exchange and the observation form, we used the following questions: To what extent did the observation form help in observing the lessons? To what extent will the criteria of the observation form help you in task setting for your own geography lessons in the future? To what extent has the exchange helped you in task setting for your own geography lessons in the future?

The answers to the questionnaires were transcribed and analysed by content analysis [108]. The qualitative data were quantified for illustrative purposes [109] (pp. 87-88). Multiple answers were taken into account. A total of 304 items were coded and categorised in 10 superordinate and 38 subordinate categories. These were formed by summarising, explicating, and structuring [110] (pp. 268-269). To analyse student teachers' answers about the quality of good tasks, we used the criteria as described in the theoretical framework as superordinate categories (Table 1). The same categories were used to analyse the student responses to a question, as well as what difficulties they experienced in task setting. These were complemented by two inductive superordinate categories; influence of the context (for example, those experienced during internships) and repertoire (regarding the tasks). In order to analyse the student teachers' answers about the observation form, another superordinate category was created that was not covered by the existing ones. This was the added value of the observation form.

Table 1. Overview of the coding manual text adventure construction activities.

\begin{tabular}{|c|c|c|}
\hline Category & Sub-Category & Example \\
\hline $\begin{array}{c}\text { Motivation and } \\
\text { engagement of students }\end{array}$ & $\begin{array}{c}\text { - variation } \\
\text { - relating to student's } \\
\text { experience/environment } \\
\text { - creative } \\
\text { - orientation towards central lesson } \\
\text { question } \\
\text { - topical } \\
\text { - activating }\end{array}$ & $\begin{array}{l}\text { "In addition, I think it is } \\
\text { important that assignments fit in } \\
\text { with the living environment of } \\
\text { the students." } \\
\text { NL-VO25_relating to } \\
\text { student's } \\
\text { experience/environment }\end{array}$ \\
\hline $\begin{array}{l}\text { Heterogeneity of } \\
\text { students }\end{array}$ & $\begin{array}{l}\text { - differentiation } \\
\text { - scaffolding }\end{array}$ & $\begin{array}{c}\text { "... so that students are helped } \\
\text { to answer a more difficult } \\
\text { question." } \\
\text { NL-MK52-scaffolding }\end{array}$ \\
\hline $\begin{array}{l}\text { Structuring Learning } \\
\text { Processes }\end{array}$ & $\begin{array}{l}\text { - logically built upon each other } \\
\text { - partial steps } \\
\text { - results debriefed and secured } \\
\text { - time management } \\
\text { - formulation (short, clear) }\end{array}$ & $\begin{array}{l}\text { "These [assignments] can be } \\
\text { structured in subtasks." } \\
\text { D-VM11-partial steps }\end{array}$ \\
\hline Comprehensibility & $\begin{array}{l}\text { - oral/written } \\
\text { - visualisation } \\
\text { - time setting } \\
\text { - action verbs }\end{array}$ & $\begin{array}{l}\text { "If tasks contain an action verb, } \\
\text { it is clear what is intended." } \\
\text { D-VC268-action verbs }\end{array}$ \\
\hline
\end{tabular}


Table 1. Cont.

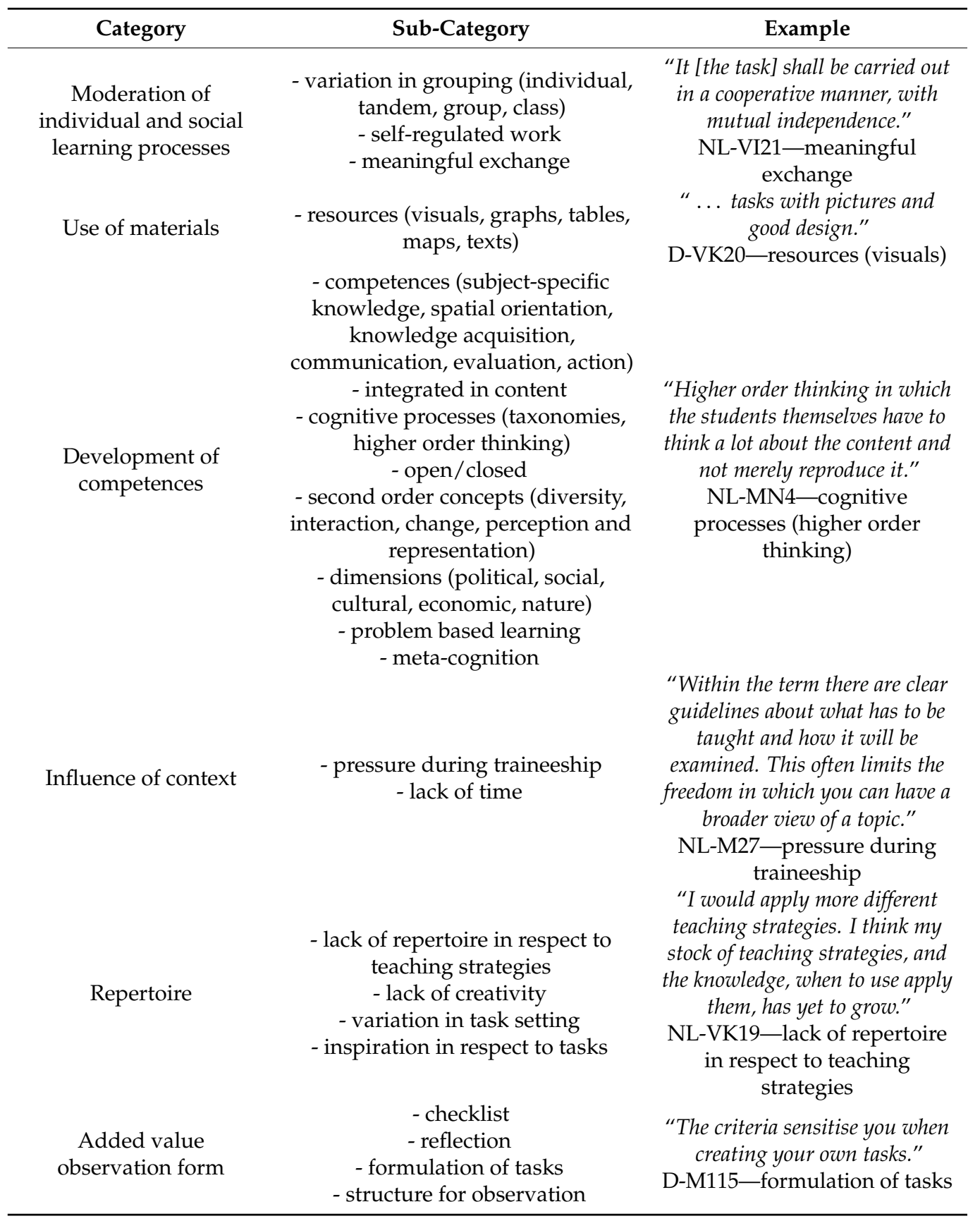

All items were coded twice by two authors. In order to achieve interrater consent [111], items where disagreement occurred (in total eight items), were discussed. An example of such an item was "securing the learning results at the end" (D-M2G), which finally was coded as 'results debriefed and secured' and a part of 'structuring learning processes' and not as 'orientation towards central lesson question' as part of 'motivation and engagement of students'.

\section{Results}

The aim of this research was to explore the student teachers' ideas about quality criteria for developing and setting tasks, the difficulties they have with regard to task setting during their teaching experience, and the added value of the developed observation form (Figure 2). We answer all three questions subsequently. First, we present aspects that 
proved to be relevant both before and after the exchange. At the end, we discuss changes that occurred during the exchange.

\subsection{Student Teachers' Ideas about Quality Criteria for Tasks and Task Setting}

For student teachers in both curriculum contexts, the development of competences through tasks is key (77 times in total). A task is considered to be good "when, after completing the assignment, students feel that they have learned something" (NL-ME34). Student teachers emphasised the development of subject specific knowledge and addressed in particular the importance of variety and an increase in complexity regarding cognitive processes: "Good tasks are tasks, which vary in level of difficulty and thus challenge students. Good questions are also questions that make students think about their own learning process or give them insight into it." (NL-MB14) "Tasks ...., which ideally increase in difficulty" (D-V65H). Furthermore, student teachers stressed that tasks should be open and based on problems.

The motivation and engagement of students was also deemed an important (44 times in total) aim of tasks the student teachers referred to. "Good geography tasks are assignments that challenge the students. According to Lambert and Balderstone, good questions are, for example, questions that activate students." (NL-MB14). Besides the activating aspect, student teachers mentioned topicality, creativity, and variation, and the Dutch student teachers particularly mentioned taking into account the everyday geographical knowledge that students already possess: "To make the connection between school geography and their own knowledge, so that new knowledge can easily be linked well to existing knowledge. I think it is important to work with examples from the student's own environment (Balderstone, 2006)." (NL-VI59).

In addition, considering the heterogeneity of learners (24 times in total) was an essential aspect of good tasks mentioned in both contexts: "Tasks which are adapted to a heterogeneous learning group" (D-MG2). Here, student teachers referred to differentiation as well as scaffolding.

The comprehensibility of tasks was not very important for the German student teachers (24 times versus twice for the Dutch student teachers). Student teachers focused on the formulation and the use of defined action verbs: "Tasks containing operators / tasks that are formulated briefly and precisely" (D-VC268). The methods of giving the tasks (oral/written) and time setting were also mentioned.

With regards to the role tasks fulfil in structuring learning processes, student teachers identified that tasks should be built upon each other in a logical way, but also that learning results should be secured properly: "The task must have a clear debriefing whereby the main conclusions are noted." (NL-VI21).

Less often student teachers referred to the moderation of individual and social learning processes (12 times in total) and the use of materials (9 times in total). However, in respect to the first aspect, student teachers emphasised that if tasks were undertaken through group work, it should be meaningful: " ... making use of a cooperative assignment, in which there is mutual independence" (NL-VI21).

Although overall student teachers mentioned nearly all quality criteria of tasks as described in the theoretical framework, in both curriculum contexts, half of the students only mentioned one or two different aspects before the course and the exchange, which can be considered as prior knowledge. Whilst the exchange did not lead to an increase in the variety of aspects Dutch student teachers mentioned, it did for the German student teachers. However, even after the exchange, the amount of student teachers referring to four or more different aspects was limited in both contexts. The biggest change for all student teachers occurred in the category 'Structuring of learning processes', which was only mentioned twice before and 16 times after the exchange. For the German student teachers, another change was visible in the comprehensibility of tasks (9 times before, 15 times afterwards). 


\subsection{Difficulties in Tasks and Task Setting}

How tasks structure learning processes is what the student teachers felt they experienced the most difficulty with in both contexts (20 items in total), particularly with regards to how to make adequate time estimations: "You never know how it's going to turn out, exactly how much time you need for an assignment" (NL-MD137). Other issues were which order and which stage should be used and how the students should be debriefed. Another issue highlighted was how to deal with heterogeneity (18 items in total), and here in particular "The differentiation in the tasks" (D-V18S) and estimating the students' level "I still find it difficult to think of what students know and are able to do at the various levels and ages" (NL-ME34).

Difficulties in realising the development of competences was more of a concern for the Dutch (15 items in total) than the German (4 items in total) student teachers. In particular, how to realise higher order thinking was a point of concern for the Dutch students: "So far, I have found it difficult to be consistent in dealing with all types of questions. I often notice that the analysis questions do not appear in the workbook or are not well formulated in the workbook (not comprehensive/deep enough). I also find analysis questions the most difficult to develop." (NL-MM18). Comprehensibility (7 items in total), use of resources (6 items in total) and moderation of individual and social learning processes ( 3 items in total) apparently caused fewer problems for the students.

Dealing with heterogeneity of students was only mentioned once in the Dutch group after the exchange took place, whereas the number of mentions was stable in the German group ( 5 items before, 6 items after). Furthermore, the Dutch student teachers focused considerably on the aspect of motivation and engagement of the students ( 8 times in total) prior to the course and exchange. This was only mentioned once by a German student teacher: "I find it difficult to get unmotivated students to work seriously when making assignments." (NL-VS1). After the exchange, this aspect was only brought up by a single Dutch student.

In particular, the Dutch student teachers became more aware of the context they were functioning in (11 items) and the importance of the (lack of) repertoire (5 items) after the course and exchange. In respect to the context, as well as the lack of time, student teachers declared that the conditions at their traineeship influenced how they dealt with tasks in the lessons: "Within the term there are clear guidelines about what has to be taught and how it will be examined. This often limits the freedom in which you can have a broader view of a topic." (NL-MH27). The insight into their lack of repertoire can best be illustrated by the following quote: "I would apply more different teaching strategies. I think my stock of teaching strategies, and the knowledge, when to use apply them, has yet to grow." (NL-VK19).

\subsection{Added Value of the Observation Form and the Exchange}

In total, $90 \%$ of the student teachers in both groups found the developed observation form helpful with respect to its use of tasks in geography lessons. The main reasons given are that it supports a more focused observation, stimulates reflection about the use of tasks, and that it helps to categorise tasks. One student said: "Through the observation form you no longer look superficially at a lesson and what you notice, but go into depth: how is everything accounted for, what types of assignments do they use, how is this in connection with Powerful Teaching etc. You structure your observation" (NL-MD137). Most of the students indicated that they would also use the observation form in the future as a checklist of quality criteria, and also during lesson preparation in order to categorise or develop tasks and when structuring learning processes.

With regard to how the exchange influenced the use of tasks in geography lessons, both groups valued the different country perspective positively. However, the Dutch student teachers indicated a higher impact, particularly in respect to securing the results during and at the end of the lesson and structuring the learning processes, the comprehensibility of tasks, more group work, and less use of PowerPoint presentations. 


\section{Discussion}

There are some limitations in this study. As the student teachers were asked to fill out the second questionnaire at the end of a tiring course, some were short of words. In the next study, the questionnaire should be given out a little earlier. However, despite the fact that our case study is only based on a small amount of thirty-three participating student teachers and dependant on the curriculum contexts of the student teachers, the outcomes show interesting results which might also be useful in other contexts.

With regards to quality criteria of tasks in geography education, student teachers are aware that tasks should contribute to the development of subject-specific competences and focus on problem-based tasks to develop higher order thinking, argumentation, and subject specific skills $[11,20,94]$. Furthermore, in their eyes, tasks should motivate students and take their everyday geographical knowledge into consideration [48]. Additionally, student teachers are sensitive to the plurality of students in their classroom and refer to differentiation as well as scaffolding [56]. In respect to comprehensibility, the way the German student teachers referenced action verbs is striking and can be explained by their curriculum context [13]. Finally, student teachers acknowledged the role of tasks in structuring lessons and referred to the fact that tasks should build upon each other [65]. These results show that student teachers develop a disciplinary understanding of their subject and their ambition to teach a good geography lesson [106]. In this sense, both universities fulfil their educational role.

However, half of the student teachers only focused on one or two quality criteria and gave less emphasis on the role tasks play in the moderation of individual and social learning processes [71] and that tasks should use resources in a meaningful way [87]. This can partly be explained by the lack of experience on the part of the student teachers and also by the fact that they rely on pre-prepared teaching materials such as textbooks, as this student explains: " ... the temptation to use the schoolbook and the assignments it contains is very high, because according to supervisors this is already enough" (NL-MV2). Yet, raising consciousness and developing competences in all aspects, but especially the moderation of individual and social learning processes and the meaningful use of materials, are important. Both aspects are key tools that should be handled deliberately by teachers in order to achieve their lesson goals, and not be left to the decisions made in textbooks, which will then lead to uncritical, limited teaching [69] (p. 69).

The main difficulties student teachers experience in their traineeships regarding task setting are linked to making adequate estimations of time, how to deal with the heterogeneity of students, and how to address higher order thinking. Whilst for the first aspect, one can argue that more experience will develop their skills, the last two aspects are difficult for experienced teachers too $[1,41,42,56]$. This means that there is a need to address these topics not only in initial teacher training but also in continuous professional development (CPD) courses.

The observation form proved to be a valuable instrument in three aspects. First of all, by how it was used during the exchanges, as a means to focus on tasks during lesson observations, but also, according to the student teachers, the form also works as a tool to prepare and reflect on lessons, with special attention on task setting during geography lessons. As tasks are vital to engage students with a subject and to achieve lesson goals $[3,27]$, and task setting is so complex because teachers have to consider numerous factors [30], it is important that all quality criteria are addressed when tasks are used, especially because they interact with one another in lesson practice [71] (p. 18). Recent research in geography education shows that coherence between learning objectives, teaching strategies (tasks), and assessment contribute to successful and meaningful learning [4]. The observation form helps student teachers, and could possibly also help experienced teachers, to get a better grip on the use of tasks during their lessons by delivering starting points for discussion and functioning as a check list.

The exchange itself was helpful as it gave the student teachers more insight into their own educational practice, which is one of the aims of a comparison [112] (p. 18) and 
confirms earlier results [103]. The German student teachers realised that their attention for content-related issues can be explained partly by a relative lack of teaching experience and a deeper focus on subject-specific education during their studies when compared with the Dutch student teachers. On the other hand, the Dutch student teachers became aware of the influence of their contexts, with a focus on the use of PowerPoint presentations, direct instruction, textbooks, and tasks aiming at lower order thinking [1].

\section{Conclusions}

In summary, developing and setting tasks in geography lessons are, because of their importance, a vital aspect that should be included in the education of geography teachers, at the training institute as well as in the workplace. Providing student teachers with theoretical knowledge is key for their professional development $[100,113]$. The observation form is a suitable instrument for student teachers, which enables the theory behind the use of tasks in geography lessons to be accessible. Generally, student teachers became more aware of the role tasks play when it came to the structuring of learning processes. German student teachers gave much more attention to the comprehensibility of tasks after the course and exchange, whereas the Dutch student teachers became less focused on the motivational aspect of tasks, but were more aware of the teaching contexts they are functioning in. Furthermore, the student teachers exchange proved to be a valuable experience as it provided new insights on the educational practice by helping student teachers become familiar with other contexts, enabling them to reflect critically on their own context.

Author Contributions: Conceptualization, U.K., A.B. and V.M.; Methodology, U.K., A.B. and V.M.; Validation, U.K., A.B. and V.M.; Formal analysis, U.K., A.B. and V.M.; Writing—original draft U.K., A.B. and V.M; Writing-review and editing, U.K., A.B. and V.M.; Visualisation, U.K., A.B. and V.M. All authors have read and agreed to the published version of the manuscript.

Funding: This research was funded by the DUTCH RESEARCH COUNCIL (NWO), grant number 023.011.001.

Institutional Review Board Statement: Not applicable.

Informed Consent Statement: Informed consent was obtained from all subjects involved in the study.

Data Availability Statement: The data presented in this study are available on request from the corresponding author. The data are not publicly available due to privacy reasons.

Conflicts of Interest: The authors declare no conflict of interest.

\section{References}

1. Krause, U.; Béneker, T.; Van Tartwijk, J.; Uhlenwinkel, A.; Bolhuis, S. How do the German and Dutch Curriculum Contexts influence (the Use of) Geography Textbooks? Rev. Int. Geogr. Educ. Online 2017, 7, 235-263.

2. Maier, V.; Budke, A. Internationalization of Teacher Education: A Case Study of Dutch and German Geography Students' Understanding of Spatial Planning. Eur. J. Geogr. 2017, 5, 43-61.

3. Kleinknecht, M. Aufgabenkultur im Unterricht: Eine Empirisch-Didaktische Video-und Interviewstudie an Hauptschulen, 1st ed.; Schneider Hohengehren: Baltmannsweiler, Germany, 2010.

4. Bijsterbosch, E.; Van der Schee, J.; Kuiper, W. Meaningful learning and summative assessment in geography education: An analysis in secondary education in the Netherlands. Int. Res. Geogr. Environ. Educ. 2017, 26, 17-35. [CrossRef]

5. Flath, M. Geographisches Schulbuch und Kompetenzerwerb-Konzeptionelle Ansätze für kompetenzorientiertes Lehren und Lernen mit einem traditionellen Medium. In Geographische Bildung. Kompetenzen in Didaktischer Forschung und Schulpraxis, 1st ed.; Meyer, C., Henrÿ, R., Stöber, G., Eds.; Westermann: Braunschweig, Germany, 2011; pp. 58-67.

6. Jo, I.; Bednarz, S. Evaluating Geography Textbook Questions from a Spatial Perspective: Using Concepts of Space, Tools of Representation, and Cognitive Processes to Evaluate Spatiality. J. Geogr. 2009, 108, 4-13. [CrossRef]

7. Wiater, W. Aufgaben im Schulbuch. In Aufgaben im Schulbuch, 1st ed.; Matthes, E., Schütze, S., Eds.; Julius Klinkhardt: Bad Heilbrunn, Germany, 2011; pp. 31-42.

8. Jordan, A.; Ross, N.; Krauss, S.; Baumert, J.; Blum, W.; Neubrand, M.; Löwen, K.; Brunner, M.; Kunter, M. (Eds.) Klassifikationsschema für Mathematikaufgaben: Dokumentation der Aufgabenkategorisierung im COACTIV-Projekt, 1st ed.; Max-Planck-Institut für Bildungsforschung: Berlin, Germany, 2006. 
9. Matthes, E.; Schütze, S. Aufgaben im Schulbuch. Einleitung. In Aufgaben im Schulbuch, 1st ed.; Matthes, E., Schütze, S., Eds.; Julius Klinkhardt: Bad Heilbrunn, Germany, 2011; pp. 9-15.

10. Rauch, M.; Wurster, E. Schulbuchforschung als Unterrichtsforschung. In Vergleichende Schreibtisch- und Praxisevaluation von Unterrichtswerken für den Sachunterricht (DFG-Projekt), 1st ed.; Lang: Frankfurt a. M., Germany, 1997.

11. Van der Schee, J. Kaarten geven te denken. In Handboek Vakdidactiek Aardrijkskunde, 1st ed.; Berg, v.d.G., Bosschaart, A., Kolkman, R., Pauw, I., Schee, v.d.J., Vankan, L., Eds.; Landelijk Expertisecentrum Mens- en Maatschappijvakken: Amsterdam, The Netherlands, 2009; pp. 197-232.

12. Anderson, L.; Krathwohl, D.; Airasian, P.; Cruikshank, K.; Mayer, R.; Pintrich, P.; Raths, J.; Wittrock, M. (Eds.) A Taxonomy for Learning, Teaching and Assessing. A Revision of Bloom's Taxonomy of Educational Objectives; Complete ed.; Longman: New York, NY, USA, 2001.

13. German Geographical Society (Ed.) Educational Standards in Geography for the Intermediate School Certificate with Sample Assignments, 2nd ed.; German Geographical Society: Bonn, Germany, 2012.

14. Van Westrhenen, J. De Toetsing van Onderwijsdoelen. Een Empirische Studie naar de Functie van Begrippen en Begripsstructuren in Het Onderwijsleerproces, 1st ed.; Wolters-Noordhoff: Groningen, The Netherlands, 1977.

15. OECD. PISA 2018 Assessment and Analytical Framework, PISA, 1st ed.; OECD Publishing: Paris, France, 2019.

16. Ananda, A.; Nofrion, N. Higher-Order Thinking Skills Improvement in Geography Learning on Material of Atmospheric Dynamic. In Proceedings of the 1st International Conference on Education Social Sciences and Humanities, West Sumatera, Indonesia, 13-16 March 2019; pp. 947-956. [CrossRef]

17. Bijsterbosch, E. Professional Development of Geography Teachers with Regard to Summative Assessment Practices, 1st ed.; Ipskamp Printing: Enschede, The Netherlands, 2018.

18. Jo, I.; Bednarz, S.; Metoyer, S. Selecting and Designing Questions to Facilitate Spatial Thinking. Geogr. Teach. 2010, 7, 49-55. [CrossRef]

19. Lane, R.; Bourke, T. Assessment in geography education: A systematic review. Int. Res. Geogr. Environ. Educ. 2017, 1-15. [CrossRef]

20. Krause, U.; Béneker, T.; Van Tartwijk, J. Thinking skills in geography textbook tasks of North Rhine Westphalia and the Netherlands. Int. Res. Geogr. Environ. Educ. 2020. Under Review.

21. Klieme, E. Unterrichtsqualität. In Handbuch Schulpädagogik, 1st ed.; Harring, M., Rohlfs, C., Gläser-Zikuda, M., Eds.; Waxmann: Münster, Germany; New York, NY, USA, 2019; pp. 393-408.

22. Maude, A.; Caldis, S. Teaching higher-order thinking and powerful geographical knowledge through the Stage 5 Biomes and Food Security unit: Higher order thinking and powerful Geography. Geogr. Educ. 2019, 32, 30-39.

23. Young, M. Powerful knowledge as a curriculum principle. In Knowledge and the Future School: Curriculum and Social Justice, 1st ed.; Young, M., Lambert, D., Roberts, C., Roberts, M., Eds.; Bloomsbury Academic: London, UK, 2014; pp. 65-88.

24. Béneker, T. Powerful knowledge in geography education. In Inaugural Lecture Given by Tine Béneker at the Acceptance of the Position of Professor of Geography E Education, at the Faculty of Geosciences, Utrecht University, at October 16th 2018; Universiteit Utrecht: Utrecht, The Netherlands, 2018.

25. Winch, C. Curriculum design and epistemic ascent. J. Philos. Educ. 2013, 47, 128-146. [CrossRef]

26. Thonhauser, J. Das Schulbuch im Spannungsfeld zwischen Wissenschaft und Ideologie. In Schulbuchforschung, 1st ed.; Olechowski, R., Ed.; Peter Lang: Frankfurt am Main, Germany, 1999; pp. 175-194.

27. Menck, P. Aufgaben-der Dreh- und Angelpunkt von Unterricht. In Aufgaben im Schulbuch, 1st ed.; Matthes, E., Schütze, S., Eds.; Julius Klinkhardt: Bad Heilbrunn, Germany, 2011; pp. 19-29.

28. Van den Akker, J. Curriculum Perspectives. An Introduction. In Curriculum Landscapes and Trends, 1st ed.; Van den Akker, J., Kuiper, W., Hameyer, U., Eds.; Kluwer: Dordrecht, The Netherlands; Boston, MA, USA; London, UK, 2003; pp. 1-10.

29. Bernstein, B. Class, Codes and Control. Volume 4. The Structuring of Pedagogic Discourse, 1st ed.; Routledge: London, UK, 1990.

30. Thijs, A.; Van den Akker, J. Leerplan in Ontwikkeling, 1st ed.; SLO: Enschede, The Netherlands, 2009.

31. Lenz, T. Lernprozesse begleiten-Leistungen bewerten. In Geographie Unterrichten Lernen. Die Didaktik der Geographie, 1st ed.; Reinfried, S., Haubrich, H., Eds.; Cornelsen: Berlin, Germany, 2015; pp. 277-308.

32. Haubrich, H. (Ed.) Geographie unterrichten lernen. In Die neue Didaktik der Geographie konkret, 1st ed.; Oldenbourg: München, Germany, 2006.

33. Nichols, A. Thinking skills and the role of debriefing. In Secondary Geography Handbook, 1st ed.; Balderstone, D., Ed.; Geographical Association: Sheffield, UK, 2006; pp. 180-197.

34. Hattie, J. Visible Learning. A Synthesis of Over 800 Meta-Analyses Relating to Achievement, 1st ed.; Routledge: London, UK, 2009.

35. Budke, A.; Kuckuck, M.; Meyer, M.; Schäbitz, F.; Schlüter, K.; Weiss, G. (Eds.) Fachlich Argumentieren Lernen. Didaktische Forschungen zur Argumentation in den Unterrichtsfächern, 1st ed.; Waxmann: Münster, Germany, 2015.

36. Sanli, C. Investigation of Question Types in High School Geography Coursebooks and their analysis in accordance with the revised Bloom's Taxonomy. Aegean Geogr. J. 2019, 26, 1-19.

37. Simon, M.; Budke, A.; Schäbitz, F. The objectives and uses of comparisons in geography textbooks: Results of an international comparative analysis. Heliyon 2020, 6. [CrossRef] [PubMed]

38. Maier, V.; Budke, A. The Use of Planning in English and German (NRW) Geography Textbooks. Rev. Int. Geogr. Educ. Online 2016, $6,8-31$. 
39. Pauw, I.; Béneker, T. A futures perspective in Dutch geography education. Futures 2015, 66, 96-105. [CrossRef]

40. Utomo, D.H.; Putri, A.E. Geography learning design based on spatial phenomenon to improve higher order thinking skills. Sumatra J. Disaster Geogr. Geogr. Educ. 2019, 3, 113-117.

41. Maier, V.; Budke, A. Wie planen Schüler/Innen? Die Bedeutung der Argumentation bei der Lösung von räumlichen Planungsaufgaben. GW-Unterricht 2018, 149, 36-49.

42. Wilcke, H.; Budke, A. Comparison as a Method for Geography Education. Educ. Sci. 2019, 9, 225. [CrossRef]

43. Yang, D.; Wang, Z.; Xu, D. A Comparison of Questions and Tasks in Geography Textbooks before and after Curriculum Reform in China. Rev. Int. Geogr. Educ. Online 2015, 5, 231-248.

44. Hieber, U.; Lenz, T.; Stengelin, M. (Sich) geographische Aufgaben stellen. Neue Aufgabenkultur im kompetenzorientierten Geographieunterricht. Geogr. Heute 2011, 291/292, 2-9.

45. Roberts, M. Geography through Enquiry. Approaches to Teaching and Learning in the Secondary School, 1st ed.; Geographical Association: Sheffield, UK, 2013.

46. Diethelm, I.; Dörge, C.; Mesaros, A.; Dünnebier, M. Die Didaktische Reduktion für den Informatikunterricht. In Proceedings of the Informatik in Bildung und Beruf. 14. GI-Fachtagung Informatik und Schule-INFOS 2011, Münster, Germany, 12-15 September 2011; Thomas, M., Ed.; Gesellschaft für Informatik e.V.: Bonn, Germany, 2011; pp. 77-86.

47. Meyer, H. Didaktische Modelle, 2nd ed.; Cornelsen Scriptor: Berlin, Germany, 2009.

48. Roberts, M. Geographical education is powerful if ... . Teach. Geogr. 2017, 42, 6-9.

49. Taylor, L. Key concepts and medium term planning. Teach. Geogr. 2008, 33, 50-54.

50. Roberts, M. Geographical Enquiry. In Secondary Geography Handbook, Sheffield: Geographical Association, 1st ed.; Balderstone, D., Ed.; Geographical Association: Sheffield, UK, 2006; pp. 90-105.

51. Janssen, F.; Hulshof, H.; Van Veen, K. Uitdagend Gedifferentieerd Vakonderwijs: Praktische Gereedschap om je Onderwijsrepertoire te Blijven Uitbreiden; ICLON/GION: Leiden/Groningen, The Netherlands, 2016.

52. United Nations. Convention on the Rights of Persons with Disabilities. 2006. Available online: https://www.un.org/ development/desa/disabilities/convention-on-the-rights-of-persons-with-disabilities.html\#Fulltext (accessed on 18 December 2020).

53. Langer, S.; Budke, A.; Ziemen, K. Migrationsbedingte Heterogenität von SchülerInnen als Herausforderung für den inklusiven Geographieunterricht. In Migration und geographische Bildung, Geographie, 1st ed.; Budke, A., Kuckuck, M., Eds.; Franz Steiner Verlag: Stuttgart, Germany, 2018; pp. 189-207.

54. Van Ackeren, I.; Klemm, K. Entstehung, Struktur und Steuerung des deutschen Schulsystems: Eine Einführung, 2nd ed.; Verlag für Sozialwissenschaften: Wiesbaden, Germany, 2011.

55. Boon, D.; Kroon, S.; Van de Ven, P.-H. Teacher Education in the Netherlands. In Europäische Lehrerbildung. Annährung an ein neues Leitbild. Berichte aus West- und Südeuropa. In Lernen für Europa-Berichte und Materialien, 1st ed.; Domovic, V., Gehrmann, S., Helmchen, J., Krüger-Potratz, M., Petravic, A., Eds.; Waxmann: Münster, Germany, 2013; Volume 2, pp. 17-46.

56. Goemans, A.; Steegen, A. Differentiatie in de Lessen Aardrijkskunde. Een Haalbare Kaart. Technieken en Methoden; Acco: Leuven, Belgium, 2015.

57. Paivio, A. Imagery and Verbal Processes, 1st ed.; Holt: New York, NY, USA, 1971.

58. Rawding, C.; Johnson, S.; Price, F. Achieving effective differentiation in geography. Teach. Geogr. 2004, $29,19-22$.

59. Uhlenwinkel, A. Binnendifferenzierung im Geographieunterricht. Prax. Geogr. 2008, 3, 4-8.

60. Brüning, L.; Saum, T. Schüleraktivierendes Lehren und Kooperatives Lernen-ein Gesamtkonzept für guten Unterricht. In Frischer Wind in den Köpfen; Special Edition; Gewerkschaft Erziehung und Wissenschaft. Landesverband Nordrhein-Westfalen, Ed.; GEW NRW: Bochum, Germany, 2011.

61. Bahr, M. Der Vielfalt mit Vielfalt begegnen—Binnendifferenzierung im Geographieunterricht. Prax. Geogr. 2013, 6, 4-9.

62. Ahlring, I. (Ed.) Differenzieren und Individualisieren, 1st ed.; Westermann: Braunschweig, Germany, 2002.

63. Bente, M. Das Schulbuch von morgen. Prax. Geogr. 1998, 4, 38-39.

64. De Boer, E.; Bustraan, J.; Goei, S.L.; De Haas, J.; Van Hameren, P.; Van Leeuwe, J. (Eds.) Handboek Zelfstandig Leren; Edumedia: Loenen aan de Vecht, The Netherlands, 1996.

65. Laske, J. Neue (?) Aufgabenkultur im Fach Geographie. Prax. Geogr. 2012, 12, 4-8.

66. Roberts, M. Learning through Enquiry. In Making Sense of Geography in the Key Stage 3 Classroom, 1st ed.; Geographical Association: Sheffield, UK, 2003.

67. Uhlenwinkel, A. Lernen im Geographieunterricht: Trends und Kontroversen. In Geographiedidaktik. Ein Arbeitsbuch zur Gestaltung des Geographieunterrichts, 1st ed.; Kanwischer, D., Ed.; Borntraeger: Stuttgart, Germany, 2013; pp. 130-140.

68. Ballstaedt, S.-P.; Mandl, H.; Schnotz, W.; Tergan, S.-O. Texte Verstehen, Texte Gestalten, 1st ed.; Urban und Schwarz: München, Germany, 1981.

69. Brooks, C. Developing and reflecting on subject expertise. In Studying PGCE Geography at M Level: Reflection, Research and Writing for Professional Development, 1st ed.; Brooks, C., Ed.; Routledge: Milton Park, UK, 2010; pp. 66-76.

70. Helmke, A. Unterrichtsqualität und Lehrerprofessionalität: Diagnose, Evaluation und Verbesserung des Unterrichts, 1st ed.; Friedrich: Seelze-Velber, Germany, 2010.

71. Meyer, H. Was ist Guter Unterricht? 1st ed.; Cornelsen Scriptor: Berlin, Germany, 2005.

72. Teunissen, F. Lesgeven op Papier: Effectieve Leerteksten Schrijven, 1st ed.; Bohn Stafleu Van Loghum: Houten, The Netherlands, 1998. 
73. Brophy, J. Teaching, 1st ed.; International Bureau of Education; Unesco: Lausanne, Switzerland, 2002.

74. Gruehn, S. Unterricht und schulisches Lernen: Schüler als Quellen der Unterrichtsbeschreibung, 1st ed.; Waxmann: Münster, Germany, 2000.

75. Tillmann, A. Gestaltung kompetenzorientierten Geographieunterrichts-Integration pädagogischer Diagnoseverfahren zur individuellen Förderung von Schülern. In Geographische Bildung: Kompetenzen in Didaktischer Forschung und Schulpraxis, 1st ed.; Meyer, C., Henrÿ, R., Stöber, G., Eds.; Westermann: Braunschweig, Germany, 2011; pp. 147-160.

76. Shannon, C.E.; Weaver, W. The Mathematical Theory of Communication, 1st ed.; University of Illinois Press: Urbana, IL, USA, 1949.

77. Rinschede, G. Geographiedidaktik, 2nd ed.; Schöningh UTB: Paderborn, Germany, 2005.

78. Sitte, C. Macht ein Führerschein allein schon einen kompetenten, vorausblickend und umsichtig agierenden Fahrer (= Teilnehmer als emanzipiertes Wirtschaftssubjekt) aus? WISO 2013, 36, 140-162.

79. Van der Schee, J. Meer Leren Denken Met Aardrijkskunde, 1st ed.; Stichting Omgeving en Educatie: Nijmegen, The Netherlands, 2006.

80. Vankan, L.; Van der Schee, J. Leren Denken Met Aardrijkskunde, 1st ed.; Stichting Omgevingeducatie: Nijmegen, The Netherlands, 2004.

81. Ebbens, S.; Ettekoven, S. Samenwerkend Leren_Praktijkboek, 4th ed.; Noordhoff Uitgevers: Groningen, The Netherlands, 2016.

82. Ballstaedt, S.P. Wissensvermittlung. Die Gestaltung von Lernmaterial, 1st ed.; Psychologie Verlags Union: Weinheim, Germany, 1997.

83. Ballstaedt, S.P. Visualisieren; UVK: Konstanz, Germany, 2012.

84. Alexander, K. Kompendium der Visuellen Information und Kommunikation, 1st ed.; Springer: Berlin/Heidelberg, Germany, 2007.

85. Erzner, F. Schulbücher für den Geographieunterricht. In Essyas zur Didaktik der Geographie, 1st ed.; Rolfes, M., Uhlenwinkel, A., Eds.; Universitätsverlag: Potsdam, Germany, 2013; pp. 55-62.

86. Janko, T.; Knecht, P. Visuals in Geography Textbooks: Categorization of Types and Assessment of Their Instructional Qualities. Rev. Int. Geogr. Educ. Online 2013, 3, 93-110.

87. Rempfler, A.; Uphues, R. Systemkompetenz im Geographieunterricht-Die Entwicklung eines Kompetenzmodells. In Geographische Bildung. Kompetenzen in Didaktischer Forschung und Praxis, 1st ed.; Meyer, C., Henrÿ, R., Stöber, G., Eds.; Westermann: Braunschweig, Germany, 2011; pp. 36-48.

88. SLO Stichting Leerplanontwikkeling. Concretisering van de Kerndoelen Mens en Maatschappij. Kerndoelen Voor de Onderbouw VO, 1st ed.; SLO: Enschede, The Netherlands, 2007.

89. Klein, H. Die neue Kompetenzorientierung: Exzellenz oder Nivellierung? Z. Didakt. Biowiss. 2010, 1, $15-26$.

90. Gohrbrandt, E.; Mäsgen, J.; Weiss, G.; Wiktorin, D. Zwischen Materialschlacht und Reproduktion. Schriftliche Zentralabituraufgaben Geographie im Bundesländervergleich und erste Erkenntnisse zu Schülerleistungen. Geogr. Sch. 2013, 35, 4-14.

91. IGU CGE (Ed.) 2016 International Charter on Geographical Education; IGU CGE: Beijing, China, 2016; Available online: https: //www.igu-cge.org/wp-content/uploads/2019/03/IGU_2016_eng_ver25Feb2019.pdf (accessed on 31 January 2021).

92. Kultusministerkonferenz (KMK). Einheitliche Prüfungsanforderungen in der Abiturprüfung. 2005. Available online: http: //www.kmk.org/fileadmin/veroeffentlichungen_beschluesse/1989/1989_12_01-EPA-Sport.pdf (accessed on 17 December 2020)

93. Ministerium für Schule und Weiterbildung des Landes Nordrhein-Westfalen [MfSuW NRW]. Geographie. Übersicht über die Operatoren. 2015. Available online: https:/ / www.standardsicherung.schulministerium.nrw.de/cms/zentralabitur-gost/faecher/ getfile.php?file=3943 (accessed on 29 October 2020).

94. Budke, A. Förderung von Argumentationskompetenzen in aktuellen Geographieschulbüchern. In Aufgaben im Schulbuch, 1st ed.; Matthes, E., Heinze, C., Eds.; Klinkhardt: Bad Heilbrunn, Germany, 2011; pp. 253-264.

95. Simon, M.; Budke, A. How Geography Textbook Tasks Promote Comparison Competency-An International Analysis. Sustainability 2020, 12, 8344. [CrossRef]

96. Clarke, D.; Hollingsworth, H. Elaborating a model of teacher professional growth. Teach. Teach. Educ. 2002, 18, 947-967. [CrossRef]

97. Neuweg, G.H. Das Wissen der Wissesnvermittler. Problemstellungen, Befunde und Perspektiven der Forschung zum Lehrerwissen. In Handbuch zur Forschung zum Lehrerberuf, 1st ed.; Terhart, E., Bennewitz, H., Rothland, M., Eds.; Waxmann: Münster, Germany, 2011; pp. 451-477.

98. Wahl, D. Lernumgebungen Erfolgreich Gestalten. Vom trägen Wissen zum Kompetenten Handeln, 1st ed.; Julius Klinkhardt: Bad Heilbrunn, Germany, 2013.

99. Krause, U.; Koster, B. Lessonstudy met de Leswizard: Een gezamenlijke leeractiviteit van leraren en aankomende leraren op de werkplek. Tijdschr. Voor Lerarenopleiders 2017, 38, 71-83.

100. Smit, E. Ik denk dat ik nu meer snap dat ik het echt nodig heb, Studenten over vakdidactiek aan de hbo-bachelor lerarenopleiding aardrijkskunde. Dimensies 2020, 1, 22-36.

101. Bronkhorst, L.H.; Meijer, P.C.; Koster, B.; Vermunt, J. Fostering meaning-oriented learning and deliberate practice in teacher education. Teach. Teach. Educ. 2011, 27, 1120-1130. [CrossRef]

102. Korthagen, F.; Kessels, J. Linking theory and practice: Changing the pedagogy of teacher education. Educ. Res. 1999, 28, 4-17. [CrossRef]

103. Budke, A.; Krause, U.; Maier, V.; Van Reumont, F.; Béneker, T. Konzepte der politischen Bildung und ihre Umsetzungen im Geographieunterricht-Ergebnisse eines deutsch-niederländischen Austauschseminars für Lehramtsstudierende. GW-Unterricht 2017, 146, 57-69.

104. Budke, A.; Kuckuck, M.; Michalak, M.; Müller, B. Erstellung kartenbasierter Argumentationen-Strukturierungs- und Formulierungshilfen. Prax. Geogr. 2016, 6, 46-48. 
105. Vankan, L.; Rohwer, G.; Schuler, S. (Eds.) Diercke Methoden 1: Denken Lernen mit Geographie, 1st ed.; Westermann: Braunschweig, Germany, 2013.

106. Appel, J. Zusammenhänge zwischen Aufgaben und Schülerbeteiligungsverhalten im Unterrichtsprozess. Ergebnisse einer Videostudie. In Aufgaben als Schlüssel zur Kompetenz: Didaktische Herausforderungen, Wissenschaftliche Zugänge und Empirische Befunde, 1st ed.; Keller, S., Reintjes, C., Abt, V., Eds.; Waxmann: Münster, Germany, 2016; pp. 261-272.

107. Bustin, R. Teaching a good Geography Lesson. In The Handbook of Secondary Geography, 1st ed.; Jones, M., Ed.; Geographical Association: Sheffield, UK, 2017; pp. 134-149.

108. Mayring, P. Qualitative Inhaltsanalyse: Grundlagen und Techniken, 12th ed.; Weinheim Basel; Beltz Verlag: Basel, Switzerland, 2015.

109. Kuckartz, U. Mixed Methods: Methodologie, Forschungsdesigns und Analyseverfahren, 1st ed.; Springer VS: Wiesbaden, Germany, 2014.

110. Mayring, P. Qualitative Content Analysis. In A Companion to Qualitative Research, 1st ed.; Flick, U., von Kardorff, E., Steinke, I., Eds.; SAGE: London, UK, 2004; pp. 266-269.

111. Kuckartz, U. Einführung in die Computergestützte Analyse Qualitativer Daten, 3rd ed.; Verlag für Sozialwissenschaften: Wiesbaden, Germany, 2010

112. Zemanek, E.; Nerbig, A. Komparatistik, 1st ed.; Akademie Verlag: Berlin, Germany, 2012.

113. Koster, B.; Stappers, J. Het Transformatiehuisje. Inzichten en Methodieken Voor Het Opleiden van Aanstaande Leraren op de Werkplek, 1st ed.; Platform Samen Opleiden: Utrecht, The Netherlands, 2019; Available online: https:/ /www.platformsamenopleiden.nl/wpcontent/uploads/2019/12/Katern-Platform-SOP-Het-transformatorhuisje.pdf (accessed on 17 December 2020). 